\title{
Kajian Hutan Kota Malabar terhadap Kenyamanan Termal
}

\author{
Eduardo Hilario Bado Towary ${ }^{1}$, Roedy Sulistyono ${ }^{2}$, Sama' Iradat Tito ${ }^{34}$, \\ Muh. Agus Ferdian 5 \\ ${ }^{1}$ Fakultas Kehutanan Institut Pertanian Malang \\ ${ }^{2}$ Budidaya Pertanian Fakultas Pertanian Universitas Brawijaya \\ ${ }^{3}$ Biologi FMIPA Unisma Malang \\ 4Pusat Studi Kelestarian dan Keseimbangan Lingkungan (Pusdi K2L) \\ FMIPA Unisma Malang \\ ${ }^{5}$ Fakultas Teknologi Pertanian Institut Pertanian Malang \\ Email : sama_iradat_tito@unisma.ac.id
}

\begin{abstract}
Comfort is something that humans need without exception when in a Green Open Space (RTH). Thermal comfort is a thermal condition felt by humans that is influenced by the environment. The existence of green space such as the City Forest of Malabar needs to be measured about it which can define its feasibility. (1) To examine the effect of thermal comfort in the Malabar forest on the community. (2) Analyzing vegetation in the Malabar city forest related to comfort. The results obtained in this study are the Temperature humidity index (THI) of respondents in the Malabar city forest known to average values of 22.42. It can be categorized that the Malabar city forest has a comfortable condition because in the index range 21 to 24 . The analysis of the vegetation analysis in the Malabar city forest is concluded for the predominant vegetation sapling level, ie the pole glodokan plant with an important value index of 6.69. Whereas the pole level that dominates is mahogany with an important value index of 6.66. As for the tree level, the dominant vegetation types are plants with an important value index of 127.91
\end{abstract}

Keywords: Malabar City Forest, Thermal Comfort, Vegetation

\section{ABSTRAK}

Kenyamanan adalah hal yang dibutuhkan manusia tak terkecuali ketika berada di Ruang Terbuka Hijau (RTH). Kenyamanan termal merupakan suatu kondisi termal yang dirasakan oleh manusia yang dipengaruhi oleh lingkungan. Keberadaan RTH seperti Hutan Kota Malabar perlu dilakukan pengukuran mengenai hal tersebut yang dapat mendefinisikan kelayakannya. (1) Untuk mengkaji pengaruh kenyaman termal dihutan kota Malabar terhadap masyarakat. (2) Menganalisis vegetasi di hutan kota Malabar yang berhubungan dengan kenyamanan. Hasil yang didapatkan pada penelitian ini adalah Temperatur humidity index (THI) terhadap responden dihutan kota Malabar diketahui rata - rata nilai sebesar 22,42. Hal tersebut dapat di kategorikan bahwa hutan kota Malabar memiliki kondisi yang nyaman karena pada rentang indeks 21 sampai 24. Hasil analisis vegetasi dihutan kota Malabar disimpulkan untuk tingkat pancang vegetasi yang mendominasi yaitu tanaman glodokan tiang dengan indeks nilai penting 6,69. Sedangkan untuk tingkat tiang yang mendominasi adalah tanaman mahoni dengan indeks nilai penting 6,66. Sedangkan untuk tingkat pohon, jenis vegetasi yang mendominasi adalah tanaman dengan indeks nilai penting 127,91

Kata kunci: Hutan Kota Malabar, Kenyamanan Termal, Vegetasi

\section{Pendahuluan}

Hutan kota malabar Hutan Kota Malabar terletak di jalan Malabar, arah timur dari gereja Ijen. Luas kawasan Hutan Kota Malabar adalah $16.718 \mathrm{~m}^{2}$. Hutan kota
Malabar tidak hanya dapat difungsikan sebagai kawasan resapan air tetapi juga dijadikan sebagai ruang aktivitas publik yang berbasis pelestarian kawasan hijau. 
Copyright (c) 2020 Al-Hayat: Journal of Biology and Applied Biology

Keberadaan hutan kota ini menjadi suatu komponen penting dalam mempertahankan kenyamanan bagi penduduk kota Malang melalui fungsinya dalam menjaga iklim mikro kota (Dinas pertamanan dan pemukiman, 2013).

Keberadaan Ruang Terbuka Hijau (RTH) sangat diperlukan bagi wilayah perkotaan, adanya RTH diharapkan mampu menanggulangi permasalahan lingkungan perkotaan terutama dalam menetralisir dampak negatif yang disebabkan oleh aktivitas perkotaan. RTH mempunyai manfaat terhadap komponen lingkungan diantaranya menyerap panas, mengurangi tingkat kebisingan dan pencemaran udara. RTH melalui perannya sebagai pengatur iklim mikro dapat menurunkan suhu permukaan yang secara langsung berpengaruh terhadap sebaran suhu udara dan dapat meningkatkan kenyamanan hidup masyarakat (Ahmad dkk, 2012).

Kenyamanan termal adalah suatu kondisi termal yang dirasakan oleh manusia yang dipengaruhi oleh lingkungan dan benda-benda disekitar melalui arsitekturnya (Frick, 2008). Pandangan ini menunjukan bahwa kenyamanan termal dipengaruhi oleh beberapa faktor salah satunya adalah lingkungan arsitekturnya, bilamana tidak sesuai dengan kaidah perencanaan maka dapat mempengaruhi kenyamanan termal suatu lingkungan.

Manusia merasa nyaman apabila suhu yang dirasakan berada pada kondisi nyaman termal. Kondisi kenyaman termal tercapai apabila kondisi badan dalam keadaan seimbang. Arti dari kondisi badan yang seimbang adalah keadaan tubuh yang mampu menyeimbangkan suhu tubuh dari proses metabolisme dengan cara evaporasi, radiasi, konduksi, dan konveksi.

Secara umum peranan vegetasi dalam suatu ekosistem hutan kota terkait dengan pengaturan keseimbangan karbon dioksida dan oksigen dalam udara, perbaikan sifat fisik, kimia dan biologis tanah, pengaturan tata air tanah dan lainlain. Meskipun secara umum kehadiran vegetasi pada suatu area hutan kota memberikan dampak positif, tetapi pengaruhnya bervariasi tergantung pada struktur dan komposisi vegetasi yang tumbuh pada daerah itu.

Vegetasi yang dapat memberikan kenyamanan lingkungan adalah vegetasi sekitar yang mampu memberikan penghawaan alami. Penghawaan alami yang baik adalah yang mampu memenuhi kebutuhan fisiologis dan psikologis penghuni. Koenigsberger (1973) menyatakan bahwa dengan kondisi iklim tropis lembab seperti di Indonesia disarankan untuk mencegah panas yang berlebih oleh vegetasi hingga tercapai keseimbangan termal yang nyaman.

Hutan kota Malabar dapat dijadikan sebagai ruang aktivitas publik. Ruang aktivitas publik yang baik harus nyaman karena kualitas suatu RTH akan meningkatkan produktifitas orang didalamnya. Aspek kenyamanan pada hutan kota adalah suhu udara, kelembaban udara dan fasilitas. Untuk mengetahui efektivitas fungsi hutan kota Malabar dalam memberikan kenyamanan khususnya kenyamanan termal terhadap masyarakat kota Malang, maka peneliti tertarik untuk mengkaji tingkat kenyamanan termal di hutan kota Malabar.

Adapun tujuan dari penelitian ini adalah. (1) Untuk mengkaji pengaruh kenyaman termal dihutan kota Malabar terhadap masyarakat. (2) Menganalisis vegetasi di hutan kota Malabar yang berhubungan dengan kenyamanan.

\section{Metode}

Lokasi Penelitian bertempat di Hutan Kota Malabar, kota Malang. Waktu Penelitian di mulai pada bulan Juli - Agustus 2019.

Alat-alat yang digunakan dalam penelitian ini adalah thermometer ruangan (Clock Humidity HTC-1) untuk mengukur suhu, hygrometer untuk mengukur tingkat kelembaban udara, pitameter untuk mengukur diameter pohon, hagameter untuk mengukur ketinggian pohon, kamera untuk mengambil gambar, alat tulis menulis.

Metode penelitian ini adalah metode observasi. Metode observasi dilakukan dengan pengamatan langsung di lapangan untuk memperoleh data atau informasi mengenai objek yang diteliti dan menganalis vegetasi yang ada dikawasan hutan kota Malabar

Data temperatur dan kelembaban relatif udara dianalisis temperatur dan kelembaban udara relatif rata-rata harian yang diukur setiap lokasi. Temperatur udara rata-rata harian dihitung dengan menggunakan rumus sebagai berikut :

$\mathrm{T}=((2 \times \mathrm{T} 07.00)+\mathrm{T} 13.00+\mathrm{T} 17.00) / 4$ (Handoko, 1995). 
Keterangan:

T07.00 = Temperatur udara yang diukur pada pukul 07.00 WIB

T13.00 = Temperatur udara yang diukur pada pukul $13.00 \mathrm{WIB}$

T17.00 = Temperatur udara yang diukur pada pukul 17.00 WIB

Kelembaban relatif (RH) rata-rata harian dihitung dengan menggunakan rumus berikut ini:

$\mathrm{RH}=(\mathrm{RH} 07.00+\mathrm{RH} 13.00+\mathrm{RH} 17.00) / 3$ (Handoko, 1995)

Keterangan:

RH07.00 = Kelembaban relatif yang diukur pada pukul 07.00 WIB

RH13.00 = Kelembaban relatif yang diukur pada pukul $13.00 \mathrm{WIB}$

RH17.00 = Kelembaban relatif yang diukur pada pukul 17.00 WIB

\section{Kenyamanan lingkungan}

Temperature Humidity Index (THI) Indonesia berada pada kisaran $20-26{ }^{\circ} \mathrm{C}$ (Irawan, 2005). Untuk mempertahankan kenyamanan di perkotaan maka perlu pengelolaan lingkungan dengan cara menurunkan suhu udara di area-area dengan suhu tinggi. Standar kenyamanan iklim mikro dapat diketahui dengan menggunakan rumus THI yang menggunakan faktor suhu dan kelembaban udara (Handoko, 1995).

Keterangan:

$$
\mathrm{THI}=0,8 \mathrm{~T}+(\mathrm{RH} \times \mathrm{T}) / 500
$$

$$
\begin{array}{ll}
\mathrm{T} & =\text { Suhu udara }\left({ }^{\circ} \mathrm{C}\right) \\
\mathrm{RH} & =\text { Kelembaban udara }(\%)
\end{array}
$$

Suhu udara dan kelembaban udara akan menentukan kenyamanan. Rentang nilai indeks kenyamanan didapat dari persamaan Nieuwolt yang dihasilkan oleh penilaian responden dengan rentang nilai sebagai berikut (Irwan, 2005):

a. Indeks $21<\mathrm{THI}<24$ Nyaman.

b. Indeks $25<\mathrm{THI}<26$ Sedang.

c. Indeks THI $>26$ Tidak nyaman.

Kenyamanan lingkungan adalah wujud dari kenyamanan fisik. Kenyamanan fisik tersebut berupa gabungan dari kenyamanan visual dan kenyamanan termal. Kenyamanan visual mudah didapatakan selaras dengan kuantitas dan kualitas peranan yang sesuai dengan fungsi masing-masing ruang. Namun kenyamanan termal ditentukan oleh faktor ekstern maupun intern.

\section{Analisis vegetasi}

Indeks Nilai Penting dihitung berdasarkan penjumlahan nilai Kerapatan Relatif (KR), Frekuensi Relatif (FR) dan Dominansi Relatif (DR), (Soerianegara dan Indrawan, 2005).

1. Diameter pohon $(\mathrm{d})=\frac{\text { Keliling }(m)}{\pi}$

2. (LBDS) pohon $=\frac{1}{4} \pi d^{2}$

3. Kerapatan $=\frac{\text { Jumlah individu suatu jenis }}{\text { Luas petak contoh }}$

4. Kerapatan Relatif

$$
=\frac{\text { Kerapatan suatu jenis }}{\text { Kerapatan seluruh jenis }} \times 100
$$

5. Frekuensi

$$
=\frac{\text { Jumlah petak ditemukan suatu jenis }}{\text { Jumlah seluruh petak yang dibuat }}
$$

6. Frekuensi Relatif

$$
=\frac{\text { Frekuensi suatu jenis }}{\text { Frekuensi seluruh jenis }} \times 10
$$

7. Dominansi (D)

$$
=\frac{\text { Jumlah LBDS suatu jenis }}{\text { Luas petak ukur }}
$$

8. Dominansi Relatif (DR)

$$
=\frac{\text { Dominansi suatu jenis }}{\text { Dominansi seluruh jenis }} \times 100
$$

9. Indeks Nilai Penting (INP)

$$
=K R+F R+D R
$$

\section{Hasil dan Pembahasan}

Pengukuran suhu relatif pada hutan kota Malabar di ambil pada lokasi titik tengah hutan kota Malabar, di tiga waktu yang berbeda dalam sehari yakni pagi jam 07:00 WIB siang 13:00 WIB dan sore 17:00 WIB. Hasil menunjukkan adanya perbedaan pada saat pengukuran di lapangan. Berikut peneliti sajikan suhu dan kelembaban pada Gambar 1 dan Gambar 2.

Pada gambar 1 dan 2 tercacat suhu dan kelembaban dihutan kota Malabar yang di ambil pada tanggal 30 juli sampai 17 agustus 2019. Pengambilan suhu dan kelembaban di ambil pada tiga waktu yang berbeda yaitu pagi, siang dan sore.

Suhu hutan kota Malabar pada pagi hari berkisar antara $17 \mathrm{C}^{\circ}-22 \mathrm{C}^{\circ}$ dan 
Copyright (c) 2020 Al-Hayat: Journal of Biology and Applied Biology

kelembaban berkisar antara 33\%-38\% pada suhu dan kelembaban tersebut peneliti menjumpai adanya aktifitas pengunjung yaitu berolahraga.

Suhu hutan kota Malabar pada siang hari berkisar $22 \mathrm{C}^{\circ}-27 \quad \mathrm{C}^{\circ}$ dan kelembaban berkisar $50 \%-71 \%$ pada suhu dan kelembaban tersebut aktifitas pengunjung berbeda dengan aktifitas di pagi hari, pengunjung lebih memilih beristirahat di bawah teduhnya vegetasi hutan kota Malabar dan memilih untuk melakukan yang tidak banyak mengeluarkan energi yaitu bersantai.

Suhu hutan kota Malabar pada sore hari berkisar antara $18 \mathrm{C}^{\circ}-23 \mathrm{C}^{\circ}$ dan kelebaban berkisar antara 44\% - 72\% pada suhu dan kelembaban tersebut aktifitas pengunjung di hutan kota Malabar mulai banyak di karenakan pada waktu sore banyak pengunjung yang memilih melepas penat dan bersantai di hutan kota Malabar. Aktivitas pengunjung di hutan kota Malabar dari waktu pagi hingga sore bervariasi, tergantung dari kebutuhan pengunjung

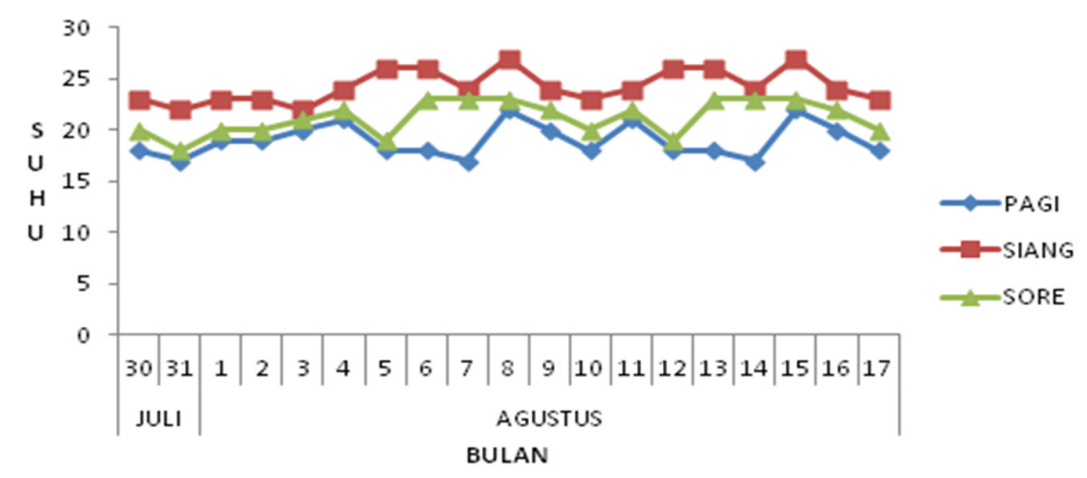

Gambar 1. Suhu hutan kota Malabar Sumber. Olah Data Pribadi, 2019

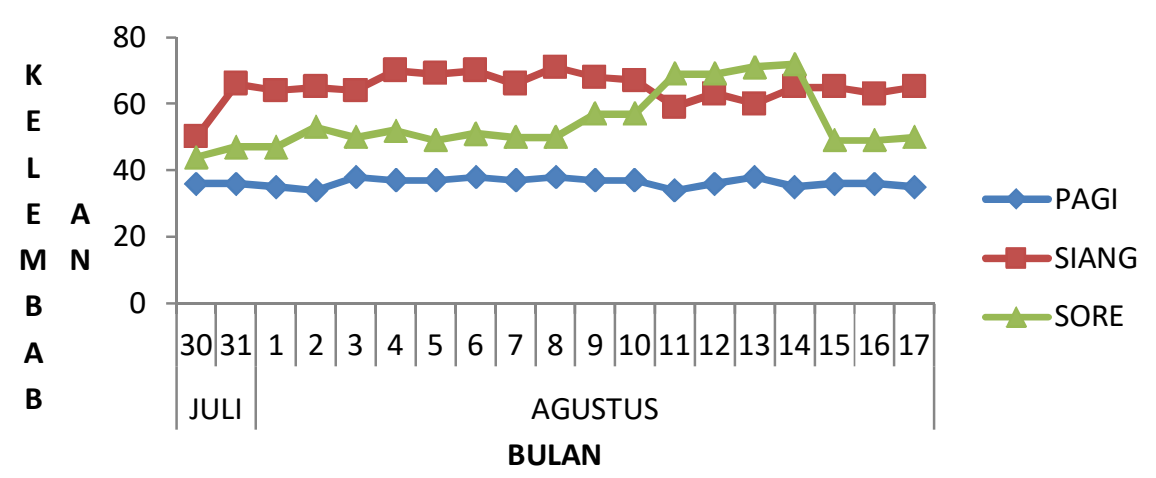

Gambar 2. Kelembaban Hutan Kota Malang Sumber: Olah Data Pribadi, 2019

\section{Kenyamanan Pengunjung di Hutan Kota Malabar}

Kenyamanan merupakan istilah yang digunakan untuk menyatakan pengaruh keadaan lingkungan fisik atmosfer atau iklim terhadap manusia. Kondisi yang nyaman adalah kondisi dimana sebagian besar energi manusia dibebaskan untuk kerja produktif, yang berhubungan dengan usaha pengaturan suhu tubuh yang minimum. Kondisi nyaman menunjukkan keadaan yang bervariasi untuk setiap individu, sehingga kenyamanan bersifat subyektif dan berhubungan dengan keadaan tingkat aktivitas, pakaian, suhu udara dan kelembaban. Nilai THI di hutan kota Malabar disajikan pada Gambar 3. 


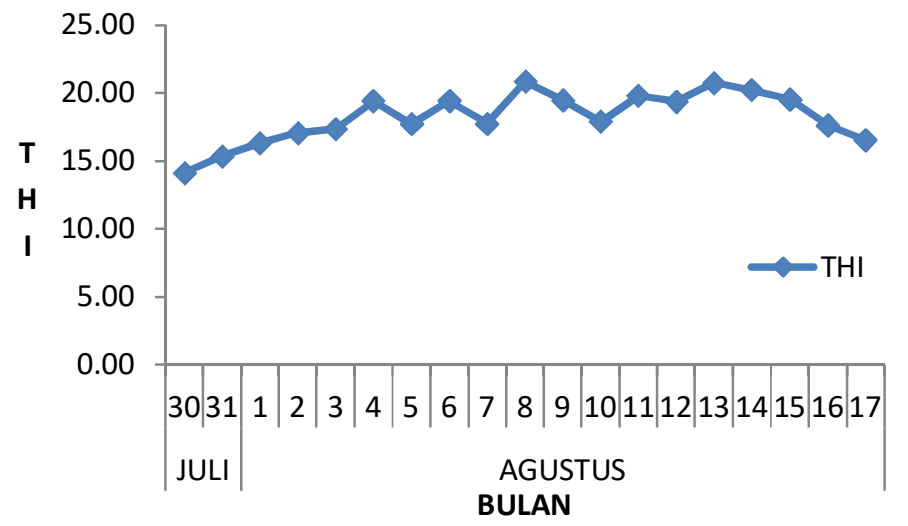

Gambar 3. Nilai THI di hutan kota Malabar.

Sumber. Data Olahan 2019

Hasil pengamatan menunjukkan bahwa nilai THI di hutan kota Malabar dalam tiga waktu yang berbeda. Penelitian termasuk dalam kategori nyaman. Nilai THI paling tinggi 20.85 dan paling rendah 14.14 dijadikan parameter kenyamanan manusia untuk beraktivitas di area tersebut. Nilai rata rata THI di hutan kota Malabar sebesar 22.42 sehingga berdasarkan penilaian nilai THI hutan kota Malabar masuk dalam kategori nyaman.

Nilai perhitungan THI hutan kota Malabar yang paling nyaman untuk pengunjung beraktifitas pada pagi hari adalah berolaharaga dan pada sore hari aktifitas pengunjung sesuai dengan kebutuhan pengunjung misalnya bersantai dibawah pohon.

\section{Analisis Vegetasi Hutan Kota Malabar}

Analisis vegetasi adalah cara mempelajari susunan (komponen jenis) dan bentuk (struktur) vegetasi atau masyarakat tumbuh-tumbuhan. Pengamatan parameter vegetasi berdasarkan bentuk hidup pohon, perdu, serta suatu ekosistem alamiah maupun binaan selalu terdiri dari dua komponen utama yaitu komponen biotik dan abiotik. Vegetasi atau komunitas tumbuhan merupakan salah satu komponen biotik yang menempati habitat tertentu seperti hutan, padang ilalang, semak belukar dan lain-lain.

Struktur dan komposisi vegetasi pada suatu wilayah dipengaruhi oleh komponen ekosistem lainnya yang saling berinteraksi, sehingga vegetasi yang tumbuh secara alami pada wilayah tersebut sesungguhnya merupakan pencerminan hasil interaksi berbagai faktor lingkungan dan dapat mengalami perubahan drastis karena pengaruh pencemaran.

Analisis vegetasi dihutan kota Malabar tingkat pancang secara keseluruan dapa disajikan pada tabel 1.

Tabel 1. Analisis Vegetasi Tingkat Pancang Di Hutan Kota Malabar

\begin{tabular}{|c|c|c|c|c|c|c|c|c|c|c|c|c|c|}
\hline No & Pohon & $\begin{array}{l}\text { Jlm } \\
\text { ind }\end{array}$ & $\mathrm{k}$ & $\mathrm{dm}$ & $\mathrm{D}^{2}$ & LBDS & $\mathrm{K}$ & $\mathrm{KR}$ & $\mathrm{F}$ & FR & $\mathrm{D}$ & DR & INP \\
\hline 1 & Klara paying & 3 & 9.5 & 3.03 & 9.15 & 0.73 & 30 & 2.65 & 1 & 0.52 & 7.29 & 0.03 & 3.21 \\
\hline 2 & Waru tutup & 4 & 9 & 2.87 & 8.22 & 0.65 & 40 & 3.54 & 1 & 0.52 & 6.54 & 0.03 & 4.09 \\
\hline 3 & Duku & 2 & 10 & 3.18 & 10.14 & 0.81 & 20 & 1.77 & 1 & 0.52 & 8.08 & 0.04 & 2.33 \\
\hline 4 & Cempaka putih & 3 & 8 & 2.55 & 6.49 & 0.52 & 30 & 2.65 & 1 & 0.52 & 5.17 & 0.02 & 3.20 \\
\hline 5 & Cerme & 2 & 10 & 3.18 & 10.14 & 0.81 & 20 & 1.77 & 1 & 0.52 & 8.08 & 0.04 & 2.33 \\
\hline 6 & Dadap hutan & 4 & 9 & 2.87 & 8.22 & 0.65 & 40 & 3.54 & 1 & 0.52 & 6.54 & 0.03 & 4.09 \\
\hline 7 & Johar & 2 & 10 & 3.18 & 10.14 & 0.81 & 20 & 1.77 & 1 & 0.52 & 8.08 & 0.04 & 2.33 \\
\hline 8 & Kemuning & 1 & 9 & 2.87 & 8.22 & 0.65 & 10 & 0.88 & 1 & 0.52 & 6.54 & 0.03 & 1.43 \\
\hline 9 & Kenari turki & 2 & 8.5 & 2.71 & 7.33 & 0.58 & 20 & 1.77 & 1 & 0.52 & 5.83 & 0.03 & 2.32 \\
\hline 10 & Pinus & 2 & 8 & 2.55 & 6.49 & 0.52 & 20 & 1.77 & 1 & 0.52 & 5.17 & 0.02 & 2.31 \\
\hline 11 & Kedoyo & 1 & 10.5 & 3.34 & 11.18 & 0.89 & 10 & 0.88 & 2 & 1.04 & 8.90 & 0.04 & 1.97 \\
\hline 12 & Sirsak & 1 & 8.5 & 2.71 & 7.33 & 0.58 & 10 & 0.88 & 2 & 1.04 & 5.83 & 0.03 & 1.95 \\
\hline 13 & Asam kranji & 2 & 8 & 2.55 & 6.49 & 0.52 & 20 & 1.77 & 2 & 1.04 & 5.17 & 0.02 & 2.83 \\
\hline
\end{tabular}


Al-Hayat: Journal of Biology and Applied Biology, Vol 3, No 1 (2020), 21-30

DOI. 10.21580/ah.v3i1.6067

Copyright (c) 2020 Al-Hayat: Journal of Biology and Applied Biology

\begin{tabular}{|c|c|c|c|c|c|c|c|c|c|c|c|c|c|}
\hline 14 & Makotha dewa & 2 & 10 & 3.18 & 10.14 & 0.81 & 20 & 1.77 & 2 & 1.04 & 8.08 & 0.04 & 2.85 \\
\hline 15 & Srikaya & 3 & 9.5 & 3.03 & 9.15 & 0.73 & 30 & 2.65 & 2 & 1.04 & 7.29 & 0.03 & 3.73 \\
\hline 16 & Palm putri & 2 & 10 & 3.18 & 10.14 & 0.81 & 20 & 1.77 & 2 & 1.04 & 8.08 & 0.04 & 2.85 \\
\hline 17 & Waru gunung & 1 & 8.5 & 2.71 & 7.33 & 0.58 & 10 & 0.88 & 2 & 1.04 & 5.83 & 0.03 & 1.95 \\
\hline 18 & Awar - awar & 2 & 10 & 3.18 & 10.14 & 0.81 & 20 & 1.77 & 2 & 1.04 & 8.08 & 0.04 & 2.85 \\
\hline 19 & Bintangur & 1 & 9 & 2.87 & 8.22 & 0.65 & 10 & 0.88 & 2 & 1.04 & 6.54 & 0.03 & 1.96 \\
\hline 20 & Agave & 1 & 8 & 2.55 & 6.49 & 0.52 & 10 & 0.88 & 2 & 1.04 & 5.17 & 0.02 & 1.95 \\
\hline 21 & Jabon & 2 & 8.5 & 2.71 & 7.33 & 0.58 & 20 & 1.77 & 2 & 1.04 & 5.83 & 0.03 & 2.84 \\
\hline 22 & Manga & 2 & 9 & 2.87 & 8.22 & 0.65 & 20 & 1.77 & 3 & 1.56 & 6.54 & 0.03 & 3.36 \\
\hline 23 & Mahoni & 4 & 10 & 3.18 & 10.14 & 0.81 & 40 & 3.54 & 3 & 1.56 & 8.08 & 0.04 & 5.14 \\
\hline 24 & Pucuk merah & 1 & 8.5 & 2.71 & 7.33 & 0.58 & 10 & 0.88 & 3 & 1.56 & 5.83 & 0.03 & 2.47 \\
\hline 25 & Rambutan & 2 & 10 & 3.18 & 10.14 & 0.81 & 20 & 1.77 & 3 & 1.56 & 8.08 & 0.04 & 3.37 \\
\hline 26 & Sawo kecik & 2 & 10.5 & 3.34 & 11.18 & 0.89 & 20 & 1.77 & 3 & 1.56 & 8.90 & 0.04 & 3.37 \\
\hline 27 & Sengon laut & 3 & 10 & 3.18 & 10.14 & 0.81 & 30 & 2.65 & 3 & 1.56 & 8.08 & 0.04 & 4.25 \\
\hline 28 & Sono & 2 & 9 & 2.87 & 8.22 & 0.65 & 20 & 1.77 & 3 & 1.56 & 6.54 & 0.03 & 3.36 \\
\hline 29 & Kembang & 2 & 9 & 2.87 & 8.22 & 0.65 & 20 & 1.77 & 3 & 1.56 & 6.54 & 0.03 & 3.36 \\
\hline 30 & Sukun & 1 & 8 & 2.55 & 6.49 & 0.52 & 10 & 0.88 & 3 & 1.56 & 5.17 & 0.02 & 2.47 \\
\hline 31 & Tapebuyan & 1 & 8.5 & 2.71 & 7.33 & 0.58 & 10 & 0.88 & 4 & 2.08 & 5.83 & 0.03 & 2.99 \\
\hline 32 & Trembesi & 2 & 10 & 3.18 & 10.14 & 0.81 & 20 & 1.77 & 4 & 2.08 & 8.08 & 0.04 & 3.89 \\
\hline 33 & Asem & 2 & 9 & 2.87 & 8.22 & 0.65 & 20 & 1.77 & 4 & 2.08 & 6.54 & 0.03 & 3.88 \\
\hline 34 & Beringin & 3 & 8.5 & 2.71 & 7.33 & 0.58 & 30 & 2.65 & 4 & 2.08 & 5.83 & 0.03 & 4.76 \\
\hline 35 & Belimbing wuluh & 2 & 9 & 2.87 & 8.22 & 0.65 & 20 & 1.77 & 4 & 2.08 & 6.54 & 0.03 & 3.88 \\
\hline 36 & Belimbing buah & 2 & 10 & 3.18 & 10.14 & 0.81 & 20 & 1.77 & 4 & 2.08 & 8.08 & 0.04 & 3.89 \\
\hline 37 & Cempaka & 2 & 10 & 3.18 & 10.14 & 0.81 & 20 & 1.77 & 4 & 2.08 & 8.08 & 0.04 & 3.89 \\
\hline 38 & Kakao & 2 & 9.5 & 3.03 & 9.15 & 0.73 & 20 & 1.77 & 4 & 2.08 & 7.29 & 0.03 & 3.89 \\
\hline 39 & Gamal & 1 & 8 & 2.55 & 6.49 & 0.52 & 10 & 0.88 & 4 & 2.08 & 5.17 & 0.02 & 2.99 \\
\hline 40 & Jati putih & 2 & 10 & 3.18 & 10.14 & 0.81 & 20 & 1.77 & 4 & 2.08 & 8.08 & 0.04 & 3.89 \\
\hline 41 & Kirai paying & 2 & 9.5 & 3.03 & 9.15 & 0.73 & 20 & 1.77 & 5 & 2.60 & 7.29 & 0.03 & 4.41 \\
\hline 42 & Waru tutup & 1 & 9 & 2.87 & 8.22 & 0.65 & 10 & 0.88 & 5 & 2.60 & 6.54 & 0.03 & 3.52 \\
\hline 43 & Pinus & 3 & 10.5 & 3.34 & 11.18 & 0.89 & 30 & 2.65 & 5 & 2.60 & 8.90 & 0.04 & 5.30 \\
\hline 44 & Sirsak & 1 & 10 & 3.18 & 10.14 & 0.81 & 10 & 0.88 & 5 & 2.60 & 8.08 & 0.04 & 3.53 \\
\hline 45 & Asam kraji & 2 & 10 & 3.18 & 10.14 & 0.81 & 20 & 1.77 & 5 & 2.60 & 8.08 & 0.04 & 4.41 \\
\hline 46 & Makotha dewa & 1 & 9 & 2.87 & 8.22 & 0.65 & 10 & 0.88 & 5 & 2.60 & 6.54 & 0.03 & 3.52 \\
\hline 47 & Johar & 2 & 9.5 & 3.03 & 9.15 & 0.73 & 20 & 1.77 & 5 & 2.60 & 7.29 & 0.03 & 4.41 \\
\hline 48 & Kenari turki & 2 & 8 & 2.55 & 6.49 & 0.52 & 20 & 1.77 & 5 & 2.60 & 5.17 & 0.02 & 4.40 \\
\hline 49 & Lamatoro & 3 & 10.5 & 3.34 & 11.18 & 0.89 & 30 & 2.65 & 5 & 2.60 & 8.90 & 0.04 & 5.30 \\
\hline 50 & Ketepeng & 2 & 9 & 2.87 & 8.22 & 0.65 & 20 & 1.77 & 6 & 3.13 & 6.54 & 0.03 & 4.92 \\
\hline 51 & Kemiri & 2 & 10 & 3.18 & 10.14 & 0.81 & 20 & 1.77 & 6 & 3.13 & 8.08 & 0.04 & 4.93 \\
\hline 52 & Kelengkeng & 1 & 9 & 2.87 & 8.22 & 0.65 & 10 & 0.88 & 6 & 3.13 & 6.54 & 0.03 & 4.04 \\
\hline 53 & Keben & 2 & 8.5 & 2.71 & 7.33 & 0.58 & 20 & 1.77 & 6 & 3.13 & 5.83 & 0.03 & 4.92 \\
\hline 54 & Kayu manis & 1 & 10 & 3.18 & 10.14 & 0.81 & 10 & 0.88 & 6 & 3.13 & 8.08 & 0.04 & 4.05 \\
\hline 55 & Jambu air & 2 & 9 & 2.87 & 8.22 & 0.65 & 20 & 1.77 & 6 & 3.13 & 6.54 & 0.03 & 4.92 \\
\hline 56 & Glodokan tiang & 4 & 9 & 2.87 & 8.22 & 0.65 & 40 & 3.54 & 6 & 3.13 & 6.54 & 0.03 & 6.69 \\
\hline 57 & Genitri & 1 & 8.5 & 2.71 & 7.33 & 0.58 & 10 & 0.88 & 6 & 3.13 & 5.83 & 0.03 & 4.04 \\
\hline \multicolumn{2}{|c|}{ Jumlah } & 113 & 527 & 167.83 & 28168 & 2242.7 & 1130 & 100 & 192 & 100 & 22427 & 100 & 300 \\
\hline
\end{tabular}

Keterangan:
k : Keliling
$\mathrm{dm}$ : diameter
$\mathrm{D}^{2} \quad$ : diameter kuadrat
LBDS : luas bidang dasar suatu jenis
K : Kerapatan
KR : Kerapatan Relative

Hasil analisis vegetasi

menunjukkan bahwa vegetasi yang paling dominan adalah tanaman glodokan tiang dengan jumlah vegetasi 4 dan memiliki indeks Nilai Penting adalah 6.69. Hal ini menunjukkan bahwa di plot 1sampai 6 tingkat pancang didominasi oleh vegetasi glodokan tiang mempunyai kemampuan bersaing yang lebih tinggi dibanding vegetasi lainnya. Dan Vegetasi yang kurang mendominasi adalah
F : Frekuensi

FR : Frekuensi Relative

D : Dominasi

DR : Dominasi Relative

INP : Indeks Nilai Penting

Sumber: Olah Data Pribadi, 2019

kemuning dengan Indeks Nilai Penting 1.43 dengan jumlah vegetasi 1.

Pohon glodokan merupakan tumbuhan evergreen yang berasal dari India, umumnya ditanam karena keefektifannya dalam mengurangi polusi suara. Kenampakan pohon ini berupa piramida simetris dengan cabang seperti pendulum dan daun lanset dengan tepi bergelombang. Pohon ini dapat tumbuh hingga mencapai 30 kaki. Akar pada 
Copyright (c) 2020 Al-Hayat: Journal of Biology and Applied Biology

glodokan ini cukup menembus ke dalam, tidak dangkal, tetapi juga tidak menjalar dengan ekstensif yang bisa mengganggu struktur seperti trotoar, jalan dan bangunan di dekatnya. Sehingga selain terdapat di hutan kota, pohon ini biasa ditanam di sepanjang pinggiran jalan sebagai peneduh jalan. Habitat dari tanaman ini terdapat di dataran rendah dengan tanah yang gembur. Glodokan

Tabel 2. Analisis Vegetasi Tingkat Tiang Di Hutan Kota Malabar

\begin{tabular}{|c|c|c|c|c|c|c|c|c|c|c|c|c|c|}
\hline No & Pohon & $\begin{array}{l}\text { Jlh } \\
\text { ind }\end{array}$ & $\mathbf{k}$ & dm & $\mathrm{D}^{2}$ & LBDS & $\mathbf{K}$ & KR & $\mathbf{F}$ & FR & D & DR & INP \\
\hline 1 & Mahoni & 2 & 38 & 12.10 & 146.46 & 11.66 & 20 & 1.80 & 1 & 0.50 & 116.61 & 0.03 & 2.34 \\
\hline 2 & Gayam & 3 & 41 & 13.06 & 170.49 & 13.57 & 30 & 2.70 & 1 & 0.50 & 135.74 & 0.04 & 3.24 \\
\hline 3 & Gamal & 1 & 33 & 10.51 & 110.45 & 8.79 & 10 & 0.90 & 1 & 0.50 & 87.94 & 0.02 & 1.43 \\
\hline 4 & Soka & 2 & 42 & 13.38 & 178.91 & 14.24 & 20 & 1.80 & 1 & 0.50 & 142.45 & 0.04 & 2.34 \\
\hline 5 & Ketapang & 1 & 25 & 7.96 & 63.39 & 5.05 & 10 & 0.90 & 1 & 0.50 & 50.47 & 0.01 & 1.42 \\
\hline 6 & Genitri & 2 & 27 & 8.60 & 73.94 & 5.89 & 20 & 1.80 & 1 & 0.50 & 58.87 & 0.02 & 2.32 \\
\hline 7 & Cemara & 1 & 39 & 12.42 & 154.27 & 12.28 & 10 & 0.90 & 1 & 0.50 & 122.82 & 0.03 & 1.44 \\
\hline 8 & Glodok tiang & 4 & 32 & 10.19 & 103.86 & 8.27 & 40 & 3.60 & 1 & 0.50 & 82.69 & 0.02 & 4.13 \\
\hline 9 & Lamatoro & 2 & 38 & 12.10 & 146.46 & 11.66 & 20 & 1.80 & 1 & 0.50 & 116.61 & 0.03 & 2.34 \\
\hline 10 & Matoa & 3 & 35 & 11.15 & 124.24 & 9.89 & 30 & 2.70 & 1 & 0.50 & 98.92 & 0.03 & 3.23 \\
\hline 11 & Jati puti & 3 & 35 & 11.15 & 124.24 & 9.89 & 30 & 2.70 & 2 & 1.01 & 98.92 & 0.03 & 3.73 \\
\hline 12 & Juwet & 1 & 32 & 10.19 & 103.86 & 8.27 & 10 & 0.90 & 2 & 1.01 & 82.69 & 0.02 & 1.93 \\
\hline 13 & Kaliandra & 2 & 36 & 11.46 & 131.45 & 10.47 & 20 & 1.80 & 2 & 1.01 & 104.65 & 0.03 & 2.83 \\
\hline 14 & Kayu putih & 2 & 40 & 12.74 & 162.28 & 12.92 & 20 & 1.80 & 2 & 1.01 & 129.20 & 0.03 & 2.84 \\
\hline 15 & Kenari & 2 & 36 & 11.46 & 131.45 & 10.47 & 20 & 1.80 & 2 & 1.01 & 104.65 & 0.03 & 2.83 \\
\hline 16 & Genitu & 2 & 40 & 12.74 & 162.28 & 12.92 & 20 & 1.80 & 2 & 1.01 & 129.20 & 0.03 & 2.84 \\
\hline 17 & Krawitan & 1 & 36 & 11.46 & 131.45 & 10.47 & 10 & 0.90 & 2 & 1.01 & 104.65 & 0.03 & 1.93 \\
\hline 18 & Ketapang & 2 & 41 & 13.06 & 170.49 & 13.57 & 20 & 1.80 & 2 & 1.01 & 135.74 & 0.04 & 2.84 \\
\hline 19 & Sengon buton & 2 & 33 & 10.51 & 110.45 & 8.79 & 20 & 1.80 & 2 & 1.01 & 87.94 & 0.02 & 2.83 \\
\hline 20 & Manga & 2 & 40 & 12.74 & 162.28 & 12.92 & 20 & 1.80 & 3 & 1.51 & 129.20 & 0.03 & 3.34 \\
\hline 21 & Matoa & 1 & 38 & 12.10 & 146.46 & 11.66 & 10 & 0.90 & 3 & 1.51 & 116.61 & 0.03 & 2.44 \\
\hline 22 & Melinjo & 1 & 35 & 11.15 & 124.24 & 9.89 & 10 & 0.90 & 3 & 1.51 & 98.92 & 0.03 & 2.43 \\
\hline 23 & Mengkudu & 2 & 37 & 11.78 & 138.85 & 11.05 & 20 & 1.80 & 3 & 1.51 & 110.55 & 0.03 & 3.34 \\
\hline 24 & Nangka & 2 & 40 & 12.74 & 162.28 & 12.92 & 20 & 1.80 & 3 & 1.51 & 129.20 & 0.03 & 3.34 \\
\hline 25 & Palem raja & 3 & 30 & 9.55 & 91.28 & 7.27 & 30 & 2.70 & 3 & 1.51 & 72.68 & 0.02 & 4.23 \\
\hline 26 & Sawo & 1 & 32 & 10.19 & 103.86 & 8.27 & 10 & 0.90 & 3 & 1.51 & 82.69 & 0.02 & 2.43 \\
\hline 27 & Rambutan & 1 & 36 & 11.46 & 131.45 & 10.47 & 10 & 0.90 & 3 & 1.51 & 104.65 & 0.03 & 2.44 \\
\hline 28 & Sukun & 2 & 40 & 12.74 & 162.28 & 12.92 & 20 & 1.80 & 3 & 1.51 & 129.20 & 0.03 & 3.34 \\
\hline 29 & Beringin & 1 & 38 & 12.10 & 146.46 & 11.66 & 10 & 0.90 & 3 & 1.51 & 116.61 & 0.03 & 2.44 \\
\hline 30 & Mahoni & 3 & 49 & 15.61 & 243.52 & 19.39 & 30 & 2.70 & 4 & 2.01 & 193.88 & 0.05 & 4.76 \\
\hline 31 & Glodokan tiang & 5 & 38 & 12.10 & 146.46 & 11.66 & 50 & 4.50 & 4 & 2.01 & 116.61 & 0.03 & 6.55 \\
\hline 32 & Glodokan lokal & 4 & 40 & 12.74 & 162.28 & 12.92 & 40 & 3.60 & 4 & 2.01 & 129.20 & 0.03 & 5.65 \\
\hline 33 & Jambu air & 2 & 35 & 11.15 & 124.24 & 9.89 & 20 & 1.80 & 4 & 2.01 & 98.92 & 0.03 & 3.84 \\
\hline 34 & Keben & 1 & 32 & 10.19 & 103.86 & 8.27 & 10 & 0.90 & 4 & 2.01 & 82.69 & 0.02 & 2.93 \\
\hline 35 & Genitri & 2 & 47 & 14.97 & 224.05 & 17.84 & 20 & 1.80 & 4 & 2.01 & 178.38 & 0.05 & 3.86 \\
\hline 36 & Kayu manis & 1 & 38 & 12.10 & 146.46 & 11.66 & 10 & 0.90 & 4 & 2.01 & 116.61 & 0.03 & 2.94 \\
\hline 37 & Lamatoro & 2 & 32 & 10.19 & 103.86 & 8.27 & 20 & 1.80 & 4 & 2.01 & 82.69 & 0.02 & 3.83 \\
\hline 38 & Kemiri & 1 & 36 & 11.46 & 131.45 & 10.47 & 10 & 0.90 & 4 & 2.01 & 104.65 & 0.03 & 2.94 \\
\hline 39 & Kersen & 1 & 44 & 14.01 & 196.36 & 15.63 & 10 & 0.90 & 4 & 2.01 & 156.34 & 0.04 & 2.95 \\
\hline 40 & Kaliandra & 2 & 39 & 12.42 & 154.27 & 12.28 & 20 & 1.80 & 4 & 2.01 & 122.82 & 0.03 & 3.84 \\
\hline 41 & Gamal & 1 & 34 & 10.83 & 117.25 & 9.33 & 10 & 0.90 & 4 & 2.01 & 93.35 & 0.02 & 2.94 \\
\hline 42 & Karet keboh & 2 & 44 & 14.01 & 196.36 & 15.63 & 20 & 1.80 & 5 & 2.51 & 156.34 & 0.04 & 4.36 \\
\hline 43 & Jati & 3 & 39 & 12.42 & 154.27 & 12.28 & 30 & 2.70 & 5 & 2.51 & 122.82 & 0.03 & 5.25 \\
\hline 44 & Juwet & 1 & 40 & 12.74 & 162.28 & 12.92 & 10 & 0.90 & 5 & 2.51 & 129.20 & 0.03 & 3.45 \\
\hline 45 & Kaliandra & 2 & 38 & 12.10 & 146.46 & 11.66 & 20 & 1.80 & 5 & 2.51 & 116.61 & 0.03 & 4.35 \\
\hline 46 & Kayu putih & 2 & 39 & 12.42 & 154.27 & 12.28 & 20 & 1.80 & 5 & 2.51 & 122.82 & 0.03 & 4.35 \\
\hline 47 & Kenari & 1 & 37 & 11.78 & 138.85 & 11.05 & 10 & 0.90 & 5 & 2.51 & 110.55 & 0.03 & 3.44 \\
\hline 48 & Genitu & 2 & 34 & 10.83 & 117.25 & 9.33 & 20 & 1.80 & 5 & 2.51 & 93.35 & 0.02 & 4.34 \\
\hline 49 & Krawitan & 1 & 37 & 11.78 & 138.85 & 11.05 & 10 & 0.90 & 5 & 2.51 & 110.55 & 0.03 & 3.44 \\
\hline 50 & Ketapang & 2 & 32 & 10.19 & 103.86 & 8.27 & 20 & 1.80 & 5 & 2.51 & 82.69 & 0.02 & 4.34 \\
\hline 51 & koro bebek & 1 & 39 & 12.42 & 154.27 & 12.28 & 10 & 0.90 & 6 & 3.02 & 122.82 & 0.03 & 3.95 \\
\hline 52 & Mindi & 1 & 37 & 11.78 & 138.85 & 11.05 & 10 & 0.90 & 6 & 3.02 & 110.55 & 0.03 & 3.95 \\
\hline 53 & Palem & 1 & 40 & 12.74 & 162.28 & 12.92 & 10 & 0.90 & 6 & 3.02 & 129.20 & 0.03 & 3.95 \\
\hline 54 & Pohon ello & 2 & 36 & 11.46 & 131.45 & 10.47 & 20 & 1.80 & 6 & 3.02 & 104.65 & 0.03 & 4.84 \\
\hline 55 & Mahoni & 4 & 42 & 13.38 & 178.91 & 14.24 & 40 & 3.60 & 6 & 3.02 & 142.45 & 0.04 & 6.66 \\
\hline
\end{tabular}

tiang juga barmanfaat sebagai tanaman penghijau yang mampu mengurangi polusi udara. Kemampuan tanaman glodokan tiang dalam menyerap karbondioksida sebanyak 32.88 $\mathrm{kg} /$ tahun. Analisis Vegetasi Tingkat Tiang secara keseluruan Di Hutan Kota Malabar dapat dilihat pada Tabel 2. 
Al-Hayat: Journal of Biology and Applied Biology, Vol 3, No 1 (2020), 21-30

DOI. 10.21580/ah.v3i1.6067

Copyright (c) 2020 Al-Hayat: Journal of Biology and Applied Biology

\begin{tabular}{|c|c|c|c|c|c|c|c|c|c|c|c|c|c|}
\hline 56 & Jatih putih & 3 & 40 & 12.74 & 162.28 & 12.92 & 30 & 2.70 & 6 & 3.02 & 129.20 & 0.03 & 5.75 \\
\hline 57 & Kayu puti & 2 & 45 & 14.33 & 205.38 & 16.35 & 20 & 1.80 & 6 & 3.02 & 163.52 & 0.04 & 4.86 \\
\hline 58 & Kesambi & 2 & 38 & 12.10 & 146.46 & 11.66 & 20 & 1.80 & 6 & 3.02 & 116.61 & 0.03 & 4.85 \\
\hline & Jumlah & 111 & 2166 & 689.81 & 475836 & 37885 & 1110 & 100 & 199 & 100 & 378851 & 100 & 300 \\
\hline
\end{tabular}

Keterangan:

k : Keliling

$\mathrm{dm}$ : diameter

$\mathrm{D}^{2}$ : diameter kuadrat

LBDS : Luas Bidang Dasar Suatu Jenis

K : Kerapatan

KR : Kerapatan Relative

Hasil analisis vegetasi menunjukkan bahwa vegetasi yang paling dominan adalah tanaman mahoni dengan jumlah vegetasi 4 dan memiliki indeks Nilai Penting adalah 6.66. Hal ini menunjukkan bahwa di plot 11 sampai 6 tingkat tiang didominasi oleh vegetasi mahoni mempunyai kemampuan bersaing yang lebih tinggi dibanding vegetasi lainnya. Dan Vegetasi yang kurang mendominasi adalah tanaman ketapang dengan Indeks Nilai Penting 1.42 dengan jumlah 1 pohon tingkat tiang.

Kemampuan tanaman mahoni dalam menyerap karbondioksida sebanyak 295,73 kg/tahun. Pohon mahoni selama ini dikenal sebagai tanaman penyejuk jalanan atau sebagai bahan untuk membuat segala bentuk
F : Frekuensi

FR : Frekuensi Relative

D : Dominasi

DR : Dominasi Relative

INP : Indeks Nilai Penting

Sumbe: Olah Data Pribadi, 2019

furniture. Berdasarkan penelitian di laboratorium, pohon mahoni (Swietenia mahagoni), termasuk pohon yang bisa mengurangi polusi udara sekitar $47 \%$ $69 \%$. Pohon mahoni yang ditanam di hutan kota atau sepanjang jalan berfungsi sebagai filter udara dan daerah tangkapan air. Daun-daunnya bertugas menyerap polutan-polutan di sekitarnya. Sebaliknya, dedaunan itu akan melepaskan oksigen $\left(\mathrm{O}_{2}\right)$ yang membuat udara di sekitarnya menjadi segar. Ketika hujan turun, tanah dan akar-akar pepohonan akan mengikat air yang jatuh, sehingga menjadi cadangan air.

Analisis vegetasi tingkat pohon secara keseluruan dapat disajikan pada Tabel 3.

Tabel 3 Analisis Vegetasi Tingkat Pohon di hutan kota Malabar

\begin{tabular}{|c|c|c|c|c|c|c|c|c|c|c|c|c|c|}
\hline No & Pohon & $\begin{array}{l}\text { Jlh } \\
\text { ind }\end{array}$ & $\mathrm{k}$ & $\mathrm{D}$ & $\mathrm{Dm}^{2}$ & LBDS & $\mathrm{K}$ & KR & $\mathrm{F}$ & FR & D & DR & INP \\
\hline 1 & Mahoni & 3 & 83 & 26.43 & 698.7 & 548.49 & 30 & 2.38 & 1 & 0.49 & 5484.87 & 1.32 & 4.19 \\
\hline 2 & Gayam & 2 & 65 & 20.70 & 428.5 & 336.39 & 20 & 1.59 & 1 & 0.49 & 3363.85 & 0.81 & 2.89 \\
\hline 3 & Beringin & 4 & 120 & 38.22 & 1460.5 & 1146.50 & 40 & 3.17 & 1 & 0.49 & 11465 & 2.75 & 6.42 \\
\hline 4 & Sengon & 2 & 100 & 31.85 & 1014.2 & 796.18 & 20 & 1.59 & 1 & 0.49 & 7961.78 & 1.91 & 3.99 \\
\hline 5 & Soka & 2 & 97 & 30.89 & 954.3 & 749.12 & 20 & 1.59 & 1 & 0.49 & 7491.24 & 1.80 & 3.88 \\
\hline 6 & Ketapang & 2 & 85 & 27.07 & 732.8 & 575.24 & 20 & 1.59 & 1 & 0.49 & 5752.39 & 1.38 & 3.46 \\
\hline 7 & Pinang & 3 & 91 & 28.98 & 839.9 & 659.32 & 30 & 2.38 & 1 & 0.49 & 6593.15 & 1.58 & 4.46 \\
\hline 8 & Nangka & 2 & 78 & 24.84 & 617.1 & 484.39 & 20 & 1.59 & 1 & 0.49 & 4843.95 & 1.16 & 3.24 \\
\hline 9 & Jati & 4 & 86 & 27.39 & 750.1 & 588.85 & 40 & 3.17 & 1 & 0.49 & 5888.54 & 1.41 & 5.08 \\
\hline 10 & Melinjo & 2 & 71 & 22.61 & 511.3 & 401.35 & 20 & 1.59 & 1 & 0.49 & 4013.54 & 0.96 & 3.04 \\
\hline 11 & Johar & 3 & 76 & 24.20 & 585.8 & 459.87 & 30 & 2.38 & 1 & 0.49 & 4598.73 & 1.10 & 3.98 \\
\hline 12 & Kenari & 2 & 90 & 28.66 & 821.5 & 644.90 & 20 & 1.59 & 1 & 0.49 & 6449.04 & 1.55 & 3.63 \\
\hline 13 & Manga & 2 & 80 & 25.48 & 649.1 & 509.55 & 20 & 1.59 & 2 & 0.99 & 5095.54 & 1.22 & 3.80 \\
\hline 14 & Mahoni & 3 & 95 & 30.25 & 915.4 & 718.55 & 30 & 2.38 & 2 & 0.99 & 7185.51 & 1.72 & 5.09 \\
\hline 15 & Melinjjo & 2 & 87 & 27.71 & 767.7 & 602.63 & 20 & 1.59 & 2 & 0.99 & 6026.27 & 1.45 & 4.02 \\
\hline 16 & Nangka & 1 & 63 & 20.06 & 402.6 & 316.00 & 10 & 0.79 & 2 & 0.99 & 3160.03 & 0.76 & 2.54 \\
\hline 17 & Sukun & 2 & 110 & 35.03 & 1227.2 & 963.38 & 20 & 1.59 & 2 & 0.99 & 9633.76 & 2.31 & 4.88 \\
\hline 18 & Sengon laut & 3 & 100 & 31.85 & 1014.2 & 796.18 & 30 & 2.38 & 2 & 0.99 & 7961.78 & 1.91 & 5.28 \\
\hline 19 & Beringin & 2 & 120 & 38.22 & 1460.5 & 1146.50 & 20 & 1.59 & 2 & 0.99 & 11465 & 2.75 & 5.32 \\
\hline 20 & Jatih putih & 4 & 109 & 34.71 & 1205.0 & 945.94 & 40 & 3.17 & 2 & 0.99 & 9459.39 & 2.27 & 6.43 \\
\hline 21 & Jabon & 2 & 85 & 27.07 & 732.8 & 575.24 & 20 & 1.59 & 2 & 0.99 & 5752.39 & 1.38 & 3.95 \\
\hline 22 & Jati & 3 & 135 & 42.99 & 1848.5 & 1451.04 & 30 & 2.38 & 3 & 1.48 & 14510.4 & 3.48 & 7.34 \\
\hline 23 & Kaliandra & 2 & 63 & 20.06 & 402.6 & 316.00 & 20 & 1.59 & 3 & 1.48 & 3160.03 & 0.76 & 3.82 \\
\hline 24 & Ketapang & 1 & 79 & 25.16 & 633.0 & 496.89 & 10 & 0.79 & 3 & 1.48 & 4968.95 & 1.19 & 3.46 \\
\hline 25 & Kayu putih & 3 & 91 & 28.98 & 839.9 & 659.32 & 30 & 2.38 & 3 & 1.48 & 6593.15 & 1.58 & 5.44 \\
\hline 26 & Soga & 2 & 101 & 32.17 & 1034.6 & 812.18 & 20 & 1.59 & 3 & 1.48 & 8121.82 & 1.95 & 5.01 \\
\hline
\end{tabular}


Al-Hayat: Journal of Biology and Applied Biology, Vol 3, No 1 (2020), 21-30

DOI. 10.21580/ah.v3i1.6067

Copyright (c) 2020 Al-Hayat: Journal of Biology and Applied Biology

\begin{tabular}{|c|c|c|c|c|c|c|c|c|c|c|c|c|c|}
\hline 27 & Pohon eloo & 2 & 96 & 30.57 & 934.7 & 733.76 & 20 & 1.59 & 3 & 1.48 & 7337.58 & 1.76 & 4.83 \\
\hline 30 & Karet keboh & 2 & 108 & 34.39 & 1183.0 & 928.66 & 20 & 1.59 & 3 & 1.48 & 9286.62 & 2.23 & 5.29 \\
\hline 32 & Rando agung & 2 & 85 & 27.07 & 732.8 & 575.24 & 20 & 1.59 & 3 & 1.48 & 5752.39 & 1.38 & 4.45 \\
\hline 33 & Lamatoro & 4 & 63 & 20.06 & 402.6 & 316.00 & 40 & 3.17 & 4 & 1.97 & 3160.03 & 0.76 & 5.90 \\
\hline 34 & Kemiri & 2 & 71 & 22.61 & 511.3 & 401.35 & 20 & 1.59 & 4 & 1.97 & 4013.54 & 0.96 & 4.52 \\
\hline 37 & Kelapa sawit & 1 & 79 & 25.16 & 633.0 & 496.89 & 10 & 0.79 & 4 & 1.97 & 4968.95 & 1.19 & 3.96 \\
\hline 38 & Kayu manis & 2 & 85 & 27.07 & 732.8 & 575.24 & 20 & 1.59 & 4 & 1.97 & 5752.39 & 1.38 & 4.94 \\
\hline 39 & Cemaranorflok & 2 & 89 & 28.34 & 803.4 & 630.65 & 20 & 1.59 & 4 & 1.97 & 6306.53 & 1.51 & 5.07 \\
\hline 40 & Akasia & 3 & 101 & 32.17 & 1034.6 & 812.18 & 30 & 2.38 & 4 & 1.97 & 8121.82 & 1.95 & 6.30 \\
\hline 41 & Cemara laut & 2 & 98 & 31.21 & 974.1 & 764.65 & 20 & 1.59 & 4 & 1.97 & 7646.5 & 1.83 & 5.39 \\
\hline 46 & Wara gunung & 2 & 78 & 24.84 & 617.1 & 484.39 & 20 & 1.59 & 5 & 2.46 & 4843.95 & 1.16 & 5.21 \\
\hline 47 & Beringin & 1 & 105 & 33.44 & 1118.2 & 877.79 & 10 & 0.79 & 5 & 2.46 & 8777.87 & 2.11 & 5.36 \\
\hline 48 & Duku & 1 & 92 & 29.30 & 858.5 & 673.89 & 10 & 0.79 & 5 & 2.46 & 6738.85 & 1.62 & 4.87 \\
\hline 49 & Cempaka put & 1 & 89 & 28.34 & 803.4 & 630.65 & 10 & 0.79 & 5 & 2.46 & 6306.53 & 1.51 & 4.77 \\
\hline 50 & Johar & 3 & 85 & 27.07 & 732.8 & 575.24 & 30 & 2.38 & 5 & 2.46 & 5752.39 & 1.38 & 6.22 \\
\hline 51 & Kemuning & 1 & 95 & 30.25 & 915.4 & 718.55 & 10 & 0.79 & 6 & 2.96 & 7185.51 & 1.72 & 5.47 \\
\hline 52 & Kenari turki & 1 & 89 & 28.34 & 803.4 & 630.65 & 10 & 0.79 & 6 & 2.96 & 6306.53 & 1.51 & 5.26 \\
\hline 53 & Pinus & 2 & 87 & 27.71 & 767.7 & 602.63 & 20 & 1.59 & 6 & 2.96 & 6026.27 & 1.45 & 5.99 \\
\hline 54 & Mahoni & 3 & 92 & 29.30 & 858.5 & 673.89 & 30 & 2.38 & 6 & 2.96 & 6738.85 & 1.62 & 6.95 \\
\hline 55 & Kayu putih & 2 & 86 & 27.39 & 750.1 & 588.85 & 20 & 1.59 & 6 & 2.96 & 5888.54 & 1.41 & 5.96 \\
\hline 56 & Ketapang & 2 & 93 & 29.62 & 877.2 & 688.61 & 20 & 1.59 & 6 & 2.96 & 6886.15 & 1.65 & 6.20 \\
\hline 57 & Sengon & 3 & 96 & 30.57 & 934.7 & 733.76 & 30 & 2.38 & 6 & 2.96 & 7337.58 & 1.76 & 7.10 \\
\hline
\end{tabular}

Keterangan:

$\mathrm{k} \quad$ : Keliling

$\mathrm{dm}:$ diameter

$\mathrm{D}^{2} \quad$ : diameter kuadrat

LBDS : Luas Bidang Dasar Suatu Jenis

K : Kerapatan

Hasil analisis vegetasi menunjukkan bahwa vegetasi yang paling dominan adalah tanaman jati putih dengan jumlah vegetasi 4 dan memiliki indeks Nilai Penting adalah 127.91. Hal ini menunjukkan bahwa di plot enam tingkat pohon didominasi oleh vegetasi jati putih yang mempunyai kemampuan bersaing lebih tinggi dibanding vegetasi lainnya. Dan Vegetasi yang kurang mendominasi adalah tanaman juwet dengan Indeks Nilai Penting 82.41.

Kemampuan tanaman jati putih menyerap karbondioksida sebanyak $135.27 \mathrm{~kg} /$ tahun. Jati berfungsi untuk mendukung kesuburan tanah karena akar pepohonannya dalam dan melebar.
KR : Kerapatan Relative

$\mathrm{F} \quad$ : Frekuensi

FR : Frekuensi Relative

D : Dominasi

DR : Dominasi Relative

INP : Indeks Nilai Penting

Sumber. Data olahan pribadi 2019

Pertumbuhan akar ini akan membantu menggemburkan tanah, sehingga memudahkan air dan udara masuk ke dalamnya. Tajuk jati akan menghasilkan serasah, yaitu jatuhan ranting, buah, dan bunga dari tumbuhan yang menutupi permukaan tanah. Serasah menjadi bahan dasar untuk menghasilkan humus tanah. Serasah pun membantu meredam entakan air hujan sehingga melindungi tanah dari erosi oleh air. Tumbuhan jati juga banyak dimanfaatkan sebagai peneduh dan penyimpan air yang baik. Dengan kata lain, pohon jati dapat berfungsi sebagai penyangga ekosistem yang dapat diunggulkan (Aynsley, 1977). 


\section{Kesimpulan}

Temperatur humidity index terhadap responden di hutan kota Malabar diketahui rata- rata nilai sebesar 22,42. Hal tersebut dapat di kategorikan bahwa hutan kota Malabar memiliki kondisi yang nyaman karena pada rentang indeks 21 sampai 24.

Hasil analisis vegetasi dihutan kota Malabar disimpulkan pada petak 1 sampai petak 6 untuk tingkat pancang terdapat 57 jenis vegetasi yang didominasi oleh tanaman yaitu tanaman glodokan tiang dengan jumlah vegetasi 4 dengan indeks nilai penting 6,69. Sedangkan untuk tingkat tiang terdapat 58 jenis vegetasi yang didominasi oleh tanaman yaitu tanaman mahoni dengan jumlah vegetasi 4 dengan indeks nilai penting 6,66. Sedangkan untuk tingkat pohon terdapat 60 jenis vegetasi yang didominasi oleh tanaman yaitu tanaman jati putih dengan jumlah vegetasi 4 dengan indeks nilai penting 127,91.

\section{Daftar Pustaka}

Ahmad, F., Arifin, H., Dahlan, E. N., Effendy, S. dan Kurniawan, R. 2012. Analisis hubungan luas ruang terbuka hijau (rth) dan perubahan suhu di Kota Palu. Jurnal Hutan Tropis. 132 : 173180.

Aynsley,R.M. 1977. Architecturel Aerodynamic. Applied Science publisher Ltd. England.

Frick,H. 2008. Ilmu Fisika Bangunan. Kanisius. Yogyakarta.

Handoko, 1995.Klimatologi Dasar. PT. DuniaPustaka Jaya.Jakarta.

Irwan, Z. 2005. Tantangan Lingkungan dan Lansekap Hutan Kota. Penerbit Bumi Aksara. Jakarta.

Koenigsberger et. Al. 1973. Manual Tropical Housing and Building, Logman Group Limited. London.

Mangunwijaya Y.B. 1997. Pengantar fisika Bangunan. Penerbit Djambatan. Jakarta 